\title{
Flora of North America North of Mexico
}

\author{
Nancy R. Morin ${ }^{1}$, Luc Brouillet ${ }^{2}$ \& Geoffrey A. Levin ${ }^{3}$
}

\begin{abstract}
The Flora of North America north of Mexico treats all native and naturalized vascular plants and bryophytes in Canada, Greenland, St. Pierre et Miquelon, and the continental United States including the Florida Keys and Aleutian Islands (approximately 18 million square kilometers). It provides accepted names, literature citations, basionyms, synonyms, morphological descriptions, habitat, geographical distribution, conservation or weed status, and a discussion of taxonomic issues for approximately 20,000 species. Of the total 30 volumes anticipated, 18 have been published and one is in press, treating 2021 genera and 12,393 species. For the remaining volumes, 763 genera and 5,008 species have been submitted, and 82 of the 144 families have been submitted in full. Completion is anticipated by the end of 2017. The project is managed by the Flora of North America Association. Content from published volumes is available through eFloras and JSTOR and has been provided to the World Flora informatics team.
\end{abstract}

Key words: Flora, North America, United States, Canada, Greenland.

\begin{abstract}
Resumo
A Flora da América do Norte ao Norte do México trata todas as espécies de plantas vasculares e briófitas ocorrente sno Canadá, Groenlândia, St. Pierre et Miquelon e na parte continental dos Estados Unidos, incluindo as Florida Keys e as Aleutian Islands (aproximadametne 18 milhões de kilômetros quadrados). Informações como nomes aceitos, citações bibliográficas, basiônimos, sinonímia, descrições morfológicas, habitat, distribuição geográfica, estado de conservação e informação sobre invasoras, bem como discussões relativas à taxonomia de aproximadamente 20.000 espécies. A previsão final é de 30 volumes, sendo que, nos 18 já publicados e naquele que está no prelo, foram tratados 2021 gêneros e 12,393 espécies. Os restantes volumes contam com a submissão de 763 gêneros e 5.008 espécies, sendo que 82 das 144 famílias estão completas. A finalização da flora está prevista para 2017. O projeto é gerenciado pela Flora of North America Association. O conteúdo dos volumes publicados está disponibilizado através de e-Floras e do JSTOR, e foi repassado para o time de informática do projeto World Flora.
\end{abstract}

Palavras-chave: Flora, Estados Unidos da América, Canadá, Groenlândia.

\section{Introduction}

The Flora of North America North of Mexico comprises treatments of vascular plants and bryophytes native or naturalized in Canada, Greenland, St Pierre et Miquelon, and the continental United States including the Florida Keys and Aleutian Islands (approximately 18 million square kilometers). Distribution information for Mexico, especially the northern tier of states, is provided, as well as generalized world-wide distribution. Treatments include accepted name, basionym, place of publication, synonyms, vernacular names, morphological descriptions, flowering time, habitat, elevation, geographical distribution, discussions, and references. Every genus and $1 / 6$ of the species are illustrated by professional botanical artists working closely with authors and editors, assuring that the drawings reflect the author's concepts and complement the technical descriptions in a way that assists the general user. Small distribution maps are provided for all species and infraspecific taxa.

\footnotetext{
${ }^{1}$ Flora of North America Association, P.O. Box 716, Point Arena, California 95468, USA. nancy.morin@nau.edu

${ }^{2}$ Institut de recherché en biologie végétale, Université de Montréal, 4101 est, rue Sherbrooke, Montréal, Québec H1X 2B2, Canada. luc.brouillet@umontreal.ca

${ }^{3}$ Illinois Natural History Survey, Prairie Research Institute, University of Illinois, 1816 S Oak St., Champaign, IL 61820, USA. levin1@illinois.edu
} 
A total of 30 volumes will be published including an introductory volume and a final volume containing a cummulative index and bibliography. As of June, 2015, eighteen volumes had been published and one was in press (Tab. 1).
Content of all published volumes is made available electronically through eFloras and JSTOR Plant Science. Preparation of all remaining volumes is projected to be completed by the end of 2017.

Table 1 - Statistics from published volumes of Flora of North America north of Mexico.

\begin{tabular}{|c|c|c|c|c|}
\hline Volume & Date published & Contents & Genera & Species \\
\hline Volume 1 & 1993 & Introductory chapters & & \\
\hline Volume 2 & 1993 & Ferns and fern allies; Gymnosperms & 97 & 553 \\
\hline Volume 3 & 1997 & Magnoliaceae to Casuarinaceae & 128 & 741 \\
\hline Volume 4 & 2003 & Phytolaccaceae to Molluginaceae & 117 & 652 \\
\hline Volume 5 & 2005 & Caryophyllaceae to Plumbaginaceae & 75 & 739 \\
\hline Volume 6 & in press & Cucurbitaceae to Droseraceae & 104 & 545 \\
\hline Volume 7 & 2010 & Salicaceae to Brassicaceae & 125 & 923 \\
\hline Volume 8 & 2009 & Paeoniaceae to Ericaceae & 125 & 682 \\
\hline Volume 9 & 2014 & Picramniaceae to Rosaceae & 74 & 691 \\
\hline $\begin{array}{l}\text { Volumes } 19, \\
20,21\end{array}$ & 2006 & Asteraceae & 418 & 2413 \\
\hline Volume 22 & 2000 & Butomaceae to Marantaceae & 89 & 423 \\
\hline Volume 23 & 2002 & Cyperaceae & 27 & 843 \\
\hline Volume 24 & 2007 & Poaceae part I & 113 & 695 \\
\hline Volume 25 & 2003 & Poaceae part II & 123 & 728 \\
\hline Volume 26 & 2002 & Pontederiaceae to Orchidaceae & 177 & 908 \\
\hline Volume 27 & 2007 & Bryophytes: Mosses part I & 127 & 704 \\
\hline \multirow[t]{2}{*}{ Volume 28} & 2014 & Bryophytes: Mosses part II & 206 & 698 \\
\hline & & Totals & 2021 & 12393 \\
\hline
\end{tabular}

\section{Brief history of Flora of North America} north of Mexico project

The scientific community has recognized the need for a continental scale flora of North America since the early 1800s. The first accounts of plants from the area were published in Europe by European botanists (e.g., in Robert Morison's Historiae [1680-1699], Leonard Plukenet's Phytographia [1691-1705], and John Ray's Historia Plantarum [1686-1704]). Fredrick Pursh's Flora Americae Septentrionalis (1814) was the first flora of continental scope. Treatises on North American plants were written by resident botanists in the early 1800 s, and the first attempt at production of a comprehensive flora of the continent was undertaken by John Torrey and
Asa Gray the 1830s (see Reveal \& Pringle 1993). Subsequently, botanists focused on producing regional floras, until 1905 when N.L. Britton began publishing the monographic series North American Flora at the New York Botanical Garden, with multiple authors. The first effort at a multiinstitutional, collaborative project started in 1966, stimulated by the completion of the Flora SSSR in 1963 (Komarov et al. 1963) and publication of the first volume of Flora Europaea in 1964 (Tutin et al. 1964). The project was to be headquartered at the Smithsonian Institution and funded ultimately through a congressional appropriation. A great deal of organizational work was done and information resources were developed but the project was suspended in 1972 because the funding plan 
was not successful. Various other attempts were made to get the project restarted, and in 1982 a group of botanists met in St. Louis and decided to try again. A plan was developed, an editorial committee formed, and in 1987 the first funding was awarded by the Pew Charitable Trusts and the National Science Foundation. Until 1996, the Missouri Botanical Garden was the organizational center through which the project was funded, after which the Flora of North America Association was incorporated and funding, along with the work force, was distributed among Editorial Centers at various institutions.

\section{Underlying philosophy of Flora of} North America north of Mexico

The mission of the Flora of North America Association (FNAA) is to make the best scientific knowledge of the plants of North America north of Mexico publicly available in consistent and easy to use forms.

To this end, FNAA coordinates the work of $900+$ botanists to provide authoritative information on the names, circumscriptions, characteristics, and geographical and ecological distributions of the 20,000 species of plants native or naturalized in North America north of Mexico.

The Flora of North America north of Mexico (FNANM) editorial committee developed policies and procedures for its completion based on recommendations made by a wide range of interested parties at a symposium titled "Floristics for the $21^{\text {st }}$ Century" (Morin et al. 1989). A guide for contributors was developed setting out style and format expectations, including that descriptions within a rank should be parallel to the extent possible and the descriptions should match the relevant entries in the identification key. The symposium participants recommended parallel descriptions so that FNANM would be more than a device to identify unknown plants; it should characterize the flora in a way useful to a wide range of audiences. Experts in each taxonomic group, when available, would be asked to write treatments of their groups in order to assure that the most authoritative, up-to-date information and taxonomic concepts were employed. Scientific reliability was deemed essential if the information was to inform management and conservation decisions. Regional reviewers (now numbering about 100) would review treatments to assure that each taxon was treated appropriately throughout its range. The editorial committee concluded that decisions should be made by the people doing the work and that authors and editors would mostly work on a volunteer basis.

\section{Content}

A "flora" may be a checklist, an identification key to included taxa, a list of accepted species with distributions, a list of accepted names with brief descriptions, literature citations, synonyms, some with maps, some with illustrations, or various combinations of these components.

Initially, the expectation was that the accounts in FNANM would be similar to those in Flora Europaea, with keys, short descriptions, minimum discussion, and no maps or illustrations, and that the entire series would comprise 14 volumes. After consideration, small distribution maps were added to help give users a quick visual impression of the geographical range of a taxon. The geographical area, continental North America north of Mexico, the Florida Keys, Aleutian Islands, St. Pierre et Miquellon, and Greenland, was selected because it forms a reasonable phytogeographical region. Mexico was not included because there were other efforts to treat that flora (regional floras, Flora Mesoamericana, Davidse et al. 1994), but distribution statements in FNANM include at least the northern tier of Mexican states when possible. Illustrations, initially for every genus and one-third of the species, were added to make the treatments more useful to non-botanists, and to show complex features difficult to portray with just words. The length of descriptions was expected to be 700 characters or less, but, for larger families and genera, the descriptions must be longer in order to make descriptions parallel and to assure that they contain features used in the key. Many of the treatments represent a botanist's lifetime of work, work that might otherwise never be published elsewhere. The editorial team has attempted to balance realistic constraints of time and resources (including a goal of completing the project within their lifetime, and physical limitations of number of pages that can be bound in one volume) with a wish to convey in the best possible way this wealth of knowledge.

\section{Taxonomic Arrangement}

When decisions were first being made about the content of Flora of North America volumes, the most comprehensive published modern 
classification system for plants was by Arthur Cronquist (1981), and that work was adopted to set the circumscriptions of families and the order in which they would appear in the volumes. Beginning in 2007, Flora of North America adopted the system outlined by the Angiosperm Phylogeny Group (2003) for remaining volumes, to the extent practicable.

Authors are encouraged to order genera and species according to their best understanding of relationships. If this is not possible, the taxa may be arranged alphabetically.

\section{Community and financial support}

In-kind support in the form of facilities and staff time has been essential for the success of the project. Editorial centers are or have been located at the The Arboretum at Flagstaff, Arizona (Volume 4), Botanical Research Institute of Texas, Fort Worth (Asteraceae, Volumes 19, 20, and 21), California Academy of Sciences, San Francisco (Volume 18 - now moving), Hunt Institute for Botanical Documentation, Pittsburgh (bibliography and Volumes 5, 6, and 14, 26, 30), Harvard University Herbaria (nomenclature), Illinois Natural History Survey, Champaign together with Canadian Museum of Nature (Volume 12), University of Kansas together with University of Michigan (Volumes 5, 8, 17), Missouri Botanical Garden (Volumes 1, 2, 3, 7, 10/11, 23, and the bryophyte volumes, 27, 28, 29), University of Montreal (Volumes 9, 13), University of Washington (Volume 15), and Utah State University (Poaceae, Volumes 24 and 25). Most editors, authors, and reviewers donate their time and expertise. Botanical artists and technical editors work on a contract basis and are coordinated by the Managing Editor and Scientific Director located at Missouri Botanical Garden. When funding has been available, a botanist has been employed on contract to write treatments for which no specialist is available. Botanical artists and technical editors, the Managing Editor, and half of the Scientific Director's time is paid by grants, contributions, art sponsorships, and earned income (royalties, etc.). Also funded are basic organizational costs such as insurance, financial audits, meetings, etc.

The botanical community has supported work on FNANM by developing cooperative groups to agree on taxonomic approaches and engaging the efforts of specialists. For example, Volumes 24 and 25, which treat Poaceae, were prepared in collaboration with a large group of grass specialists working through Utah State University and funded in part by the U.S. Department of Agriculture. Volumes 19, 20, and 21, treating Asteraceae, were prepared under the guidance of a team of noted synantherologists coordinated at the Botanical Research Institute of Texas and funded by a grant from the U. S. National Science Foundation. Volumes 27, 28, and 29, Bryophytes, are being completed by a team of bryologists.

The initial funding for the current Flora of North America project from the Pew Charitable Trusts was matched by a grant from the U. S. National Science Foundation, which made additional grants through 1999. A wide range of foundations made grants to the project from 1987 through 1999. The Chanticleer Foundation provided core funding 2000-2008. The Andrew W. Mellon Foundation and an anonymous foundation also provided core funding in 2008 through 2012. Funding since 2012 has been received from the Philecology Foundation, the Franklinia Foundation, the David and Lucile Packard Foundation and other organizations and individuals.

\section{Information Technology}

The original Flora North America project was far ahead of its time in its vision of management and analysis of botanical data using computers. The 1967 proposal to NSF outlined goals of developing an information retrieval system and the ability to automatically update information continuously and retrieve it in newly combined forms. At the time, research indices like Index Kewensis were compiled by hand. The FNA organizers hoped they could provide the initial stimulus and technical foundation for development of comprehensive information retrieval systems.

The current Flora of North America organizers decided to focus their efforts on acquiring the botanical treatments rather than developing information management tools. Nonetheless, the potential for using computers to assist with preparation of the flora was kept in mind. (Before the World Wide Web became publicly available in 1990, all manuscripts were duplicated and distributed using the U. S. Postal Service.) TROPICOS, a system developed by Missouri Botanical Garden botanists Robert Magill and Marshall Crosby in the early 1980s to manage plant nomenclature and bibliography, was adopted as the system in which FNA nomenclature 
would be maintained. A bibliographic database for FNA was developed by Robert Kiger at the Hunt Institute for Botanical Documentation. Grants from the U. S. National Science Foundation supported development of innovative tools for collaborative work processes, envisioning the potential for multiple participants to work on the same manuscript and to monitor tasks and accomplishments. An initial goal of creating a massive relational database of characteristics has evolved into the use of semantic markup tools developed by James Macklin and Hong Cui (Cui 2010; Morris et al. 2013). Treatments parsed into their basic components are available through eFloras (<http://www.efloras.org $>$ ) and JSTOR (<http://www.plants.jstor.org $>$ ). Resource materials for authors and reviewers, links to published volumes, status of volumes in preparation, and other information about the FNANM project, are available on the FNA website: www.floranorthamerica.org. In the past year the FNA website received about 1,371,540 successful requests for 377,356 pages - on average 26,000 successful requests per week.

\section{Progress to date}

Flora of North America now has published 18 of the total 30 volumes and has one volume in press (Volumes 1-9, 19-28; 11,200 pages), containing 253 families, 2,125 genera, and 12,949 species (Flora of North America Editorial Committee, 1993+). These volumes also contain original illustrations of 7,200 species, subspecies, or varieties and maps of every species and infraspecific taxon. Volume 1, published in 1993, includes introductory chapters on the history of floristics and plant collecting in North America; climate and physiography; soils; history of the vegetation and paleoclimates, vegetation, and floras; vegetation, and phytogeography.

\section{Completing Flora of North America north of Mexico by 2020}

The taxonomic volumes remaining to be completed: Volumes 10-18 and 29, contain 144 families, 1103 genera, and 7365 species. Of these, 763 genera and 5008 species have been submitted, and 82 of the 144 families have been submitted in full. Volume 12, Vitaceae to Garryaceae, 29 families, 122 genera, and 760 species, is in final stages of editing and will be in press this fall. Volume 17, Polypremaceae to Orobanchaceae, containing 9 families, 94 genera, and 942 species, will be in press by the end of 2015 or early 2016 . For Volumes 10 and 11, being prepared together and containing largely Fabaceae and Onagraceae, all but those two families have been submitted in full and $91 \%$ of the genera and species are in hand and in process of review, revision, and editing. For the remaining five volumes containing treatments of vascular plants, more than half of the families and genera have been submitted and are being edited. All other treatments have authors assigned and are in preparation. The final Bryophyte volume, containing liverworts and hornworts, is also making good progress. Status of individual treatments in volumes to be published can be found at www. floranorthamerica.org.

\section{Methodology}

Each volume is assigned to an editorial center under the leadership of a lead editor (or co-lead editors). Each family is assigned to a taxon editor who works directly with authors, reviewers, and technical editors. Authors are selected based on their interest and expertise and with approval of the FNAA Board. Technical editors work on a contract basis; each one is assigned to a volume. Regional review is managed by regional coordinators, who send draft treatments to reviewers knowledgeable in their local flora and compile responses, which are returned to taxon editors. Authors provide material to botanical artists so they can prepare illustrations. Every genus and about one in six species are illustrated by these contract artists. Authors are asked to use terminology set out in (Kiger \& Porter 2001). Names accepted in major regional floras are supplied to authors and are to be accounted for in the treatments. Robert Kiger, Hunt Institute for Documentation, edits all bibliographic references and compiles the cumulative bibliography. Kanchi Gandhi, Harvard University Herbaria, reviews nomenclature and citations. Some aspects of final production, such as indexing and page composition, are carried out by contract workers under the supervision of Heidi Schmidt, managing editor, and James Zarucchi, editorial director, who also oversee all manuscript flow.

Challenges for completion include editorial capacity and time available to volunteer authors and reviewers. Botanists with broad floristic knowledge are becoming scarce, and there are plant groups for which no specialist is available. Fortunately, FNANM has been able to enlist the help of botanists who have recently completed their graduate degrees or are currently graduate students. 
Resources for completing the Flora of North America north of Mexico

\section{Regional Floras}

The Flora of North America project draws on a wealth of resources. A working checklist has been available from several sources, including the United States Department of Agriculture PLANTS database and The Natural Heritage Program through its Natureserve database. Canada has a working checklist through VASCAN, part of Canadensys.

North America north of Mexico is a very large geographic area, politically and biogeographically diverse, so it is understandable that floristic work has focused on states, provinces, or regions. Regional floras recently completed for the United States include The Jepson Manual, covering all of California (Baldwin et al. 2012); the Intermountain Flora, covering all of the Great Basin (Cronquist et al. 1972); Flora of the Southern and MidAtlantic States (Weakley 2012); and Flora Novae Angliae (Haines 2011). Less recent but still important are Flora of the Great Plains (Great Plains Flora Association 1986); Manual of the Vascular Plants of Texas (Correll \& Johnston 1970); and Manual of vascular plants of northeastern United States and adjacent Canada, second edition (Gleason \& Cronquist 1991).

For Canada, a basic reference is the Flora of Canada (Scoggan 1978-1979); Budd's Flora of the Canadian Provinces (Budd et al. 1987); The vascular plants of British Columbia (Douglas et al. 1989-1994); Vascular plants of the continental Northwest Territories (Porsild \& Cody 1980); Flore Laurentienne (Marie-Victorin, revised by Brouillet et al. 1995); Atlas of the vascular plants of the island of Newfoundland and of Saint Pierre et Miquelon (Rouleau and Lamoureux 1992); and The flora of New Brunswick (Hinds 2000). In preparation is a Flora of the vascular plants of the Canadian Arctic Archipelago, updating the Illustrated Flora of the Canadian Arcitc Archipelago (Porsild 1964).

\section{Online specimen, occurrence, and nomenclatural databases}

Some regional or state specimen databases also functionally serve as checklists. They are a rich resource for authors and reviewers. As Flora of North America volumes are published, the databases are updated to reflect new classifications. Examples of such databases are: Country-wide Databases
2.1 Canadensys (<http://data.canadensys.net/ explorer/en/search $>$ )

The checklist covers all vascular plants reported in Canada, Greenland (Denmark), and Saint Pierre and Miquelon (France). The latter two regions are added because their floras are intimately related to that of Canada. Provincial distributions are provided to help users visualize the relationship among the floras of Canadian provinces and territories. VASCAN does not intend to replace regional or provincial lists but to act as a complement to them. The covered regions are, in alphabetical order: Alberta, British Columbia, Greenland, Labrador, Manitoba, New Brunswick, Newfoundland, Northwest Territories, Nova Scotia, Nunavut, Ontario, Prince Edward Island, Quebec, Saint Pierre and Miquelon, Saskatchewan, and Yukon. The distribution status of the plant is indicated per region. These can be grouped as present (native, introduced or ephemeral), previously reported but currently considered absent (excluded, extirpated), doubtful or not reported (absent). The latter status is not recorded in the database (null value). Excluded taxa are those considered not currently occurring in a region, due either to nonrecurring ephemeralness, misidentification, lack of supporting documentation, or when specimens are old and the taxon has not been observed again in more than 50 years. All distribution statuses are defined at $(<\mathrm{http}: / /$ data.canadensys.net/vascan/ about/\#distribution $>$ ). The VASCAN website $(<\mathrm{http} / / /$ data.canadensys.net/vascan $>)$ provides a distribution map for each taxon.

2.2 The PLANTS Database ( $<$ http://plants.usda. gov $>$ )

Provides standardized information about the vascular plants, mosses, liverworts, hornworts, and lichens of the U.S. and its territories. It includes names, plant symbols, checklists, distributional data, species abstracts, characteristics, images, crop information, automated tools, onward Web links, and references. It can be searched by taxonomy, morphological and habitat characteristics, geographical distribution, and weed, wetland, and conservation status.

\section{Specimen Databases available online that also can generate checklists}

Most of these online databases are collaborations among regional networks of herbaria and provide links to the individual member organizations. 
3.1 Canadensys Explorer ( $<$ http://data. canadensys.net/explorer $>$ )

Serves 180,000 vascular plant specimen records from 13 Canadian herbaria.

\subsection{Consortium of California Herbaria $(<\mathrm{http}: / /$} ucjeps.berkeley.edu/consortium>)

The Consortium of California Herbaria provides data from over 2 million specimen records from over 30 institutions.

\subsection{Consortium of Pacific Northwest Herbaria} ( $<$ http://www.pnwherbaria.org $>$ )

The Consortium of Pacific Northwest Herbaria hosts more than 2.4 million specimen records from 33 herbaria in Alaska, Idaho, Montana, Oregon, Washington, Wyoming, British Columbia, Yukon Territory, and Humboldt State University in northern California.

\subsection{Intermountain Regional Herbarium Network} ( $<$ http://intermountainbiota.org/portal/index.php $>$ )

The Intermountain Regional herbarium Network hosts collection data from herbaria in Nevada and Utah. (also served throught SEINET: $(<\mathrm{http}$ ://swbiodiversity.org/seinet/index.php $>)$ ).

\subsection{Southwest Environmental Information Network} ( $<$ http://swbiodiversity.org/seinet/index.php $>$ )

The Arizona Chapter of SEINET serves collections and observation data from 14 institutions in Arizona. SEINet allows searching across many major regional herbarium networks.

3.6 Flora of Texas Database (<http://w3.biosci. utexas.edu/prc/Tex.html $>$ )

Serves records of occurrences in Texas based on University of Texas and Lundell herbaria.

\subsection{Rocky Mountain Regional Consortium} Specimen Database ( $<$ http://www.rmh.uwyo.edu $>$ ) Provides searching across 14 herbaria in Colorado, Idaho, Montana, and Wyoming (also served throught SEINET: (<http://swbiodiversity. org/seinet/index.php $>)$ ).

\subsection{Consortium of Midwest Herbaria ( $<\mathrm{http}: / /$ midwestherbaria.org/portal $>$ ) \\ Hosts specimen data from 21 herbaria in Illinois, Indiana, Iowa, Michigan, Minnesota, Ohio, and Wisconsin. (also served through SEINET: $(<\mathrm{http}$ ://swbiodiversity.org/seinet/index.php $>))$.}

3.9 Northern Great Plains Herbaria $(<\mathrm{http}: / /$ www.ngpherbaria.org $>$ )

Hosts data from 19 herbaria in Illinois, Iowa, Kansas, Minnesota, Missouri, Nebraska, North Dakota, and South Dakota, (also served through SEINET: $(<\mathrm{http}: / /$ swbiodiversity.org/seinet/index. php>)).

\subsection{Consortium of Northeastern Herbaria} $(<\mathrm{http}: / /$ portal.neherbaria.org $>)$

Serves 776,600 records of vascular plants and bryophytes from 21 herbaria in Nova Scotia, Quebec; Connecticut, Massachusetts, New Hampshire, New Jersey, New York, Pennsylvania, Rhode Island, and Vermont.

\subsection{Southeast Regional Network of Expertise} and Collections $(<\mathrm{http}: / /$ sernec.appstate.edu $>$ )

Hosts records from 110 herbaria in Alabama, Arkansas, Delaware, Florida, Georgia, Kentucky, Louisiana, Maryland, Mississippi, North Carolina, South Carolina, Tennessee, Texas, Verginia, and West Virginia (also served through SEINET: $(<\mathrm{http}$ ://swbiodiversity.org/seinet/index.php $>))$.

\subsection{Atlas of Florida vascular Plants $(<\mathrm{http}: / /$} www.florida.plantatlas.usf.edu $>$ )

Serves records from over 110,000 herbarium specimens from 8 herbaria in Florida.

\section{Conclusion}

Improving the knowledge of the Flora of North America north of Mexico

Flora of North America north of Mexico has stimulated the completion and publication of research by authors of treatments and presents the best, most current understanding of the relationships, characteristics, and distribution of plants in the flora. It brings together in a standard, carefully reviewed form, the results of lifetimes of study and the findings of the most recent research. Aspects of phylogeny, biology, or ecology that need more study are mentioned in the discussion, which stimulates new research. Because the descriptions and discussion characterize the plants in more detail than more abbreviated floras or checklist, they provide a rich resource for research by ecologists, plant breeders, plant morphologists, physiologists, to name just a few. This resource will be much enhanced by the current effort to parse all descriptions, distributions, and habitats from published volumes. 
Importance of Flora of North America for Environmental Research

Flora of North America provides a common reference for the circumscription of plant taxa, correct application of names to those taxa, and descriptive information for each taxon. This is critically important for every kind of research from broad ecological studies to phenomics, genomics, and phylogenetic analysis. Although there are checklists of the plants of North America already available, none have the same level of scientific authority, and, since they lack descriptions, they are not sufficient to determine what is actually included within the named concept. There are few equivalents in terms of digital datasets in the animal or insect worlds, and none dealing with as many species.

\section{Importance of the World Flora}

It would be highly useful for further research, for conservation, and for resource management to have a common reference for the circumscription of plant taxa, correct application of names to those taxa, and descriptive information for each taxon, and worldwide distribution for all plants. Only elements of this, in various guises, are so far available. For Flora of North America north of Mexico, based on volumes published to date, $13 \%$ of the genera and $50 \%$ of the species are endemic to the flora area. FNANM has provided full descriptions and abbreviated worldwide distributions for 6500 species that also occur outside the flora area and for nearly 1900 genera that also occur outside the flora area. Of these, 315 of the genera and 1791 of the species in published volumes are introduced. Currently it is very difficult for authors to find the relevant data on the non-native taxa, as it must be for researchers outside North America to find data on the 10,000 species likely to be endemic in North America north of Mexico, since much of that information is contained in local floras or individual monographs. A World Flora would facilitate access to these data.

Integrating Flora of North America north of Mexico data with the World Flora

All published treatments are available in electronic form, and soon all will be fully parsed into individual components. The electronic files for volumes published have already been provided to the World Flora Online for incorporation.

\section{References}

Angiosperm Phylogeny Group. 2003. An update of the Angiosperm Phylogeny Group classification for the orders and families of flowering plants: APG II. Botanical Journal of the Linnean Society 141: 399-436.

Baldwin, B.G.; Goldman, D.; Keil, D.J.; Patterson, R.; Rosatti, T.J. \& Wilken, D. (eds.). 2012. The Jepson manual: vascular plants of California, revised and expanded. University of California Press, Berkeley. $1568 \mathrm{p}$.

Britton, N.L. et al. (eds.). 1905. North American Flora. 47 vols. New York Botanical Garden, New York. Vols. 1-34, 1905-1957; ser. 2, parts 1-13, 1954.

Budd, A.C.; Looman, J. \& Best, K.F. 1987. Budd's flora of the Canadian Prairie Provinces, revised and enlarged. Publication 1662. Agriculture Canada Research Branch, Ottawa and Hull. 863p.

Correll, D.S. \& Johnston, M.C. 1970. Manual of the vascular plants of Texas. Texas Research Foundation, Renner. 1881p.

Cronquist, A. 1981. An integrated system of classification of flowering plants. Columbia University Press, New York. 1262 p.

Cronquist, A.; Holmgren, A.H.; Holmgren, N.H.; Reveal, J.L.; Holmgren, P.K. \& Barneby, R.C. 1972+. Intermountain Flora. Vascular plants of the Intermountain West, U.S.A. 8 vols. New York Botanical Garden, New York and London. 3865p.

Cui, H. 2010. Semantic annotation of morphological descriptions: an overall strategy. BMC Bioinformatics 11: 278.

Davidse, G.; Sousa S.M. \& Chater, A.O. et al. (eds.). 1994+. Flora Mesoamericana. 4 vols. Universidad Nacional Autónoma de México, Instituto de Biología, Ciudad Universitaria, Mexico City. Missouri Botanical Garden Press, St. Louis. 2788p.

Flora of North America Editorial Committee (eds.). 1993+. Flora of North America North of Mexico. $19+$ vols. Oxford University Press, New York and Oxford. 12,303p.

Douglas, G.W.; Straley, G.B. \& Meidinger, D.V. 19891994. The vascular plants of British Columbia. 4 vols. British Columbia Ministry of Forests, Special Report, Victoria. 800p.

Great Plains Flora Association. 1986. Flora of the Great Plains. University Press of Kansas, Lawrence. 1382p.

Gleason, H.A. \& Cronquist, A. 1991. Manual of vascular plants of northeastern United States and Adjacent Canada. $2^{\text {nd }}$ ed. New York Botanical Garden, Bronx. $910 \mathrm{p}$.

Haines, A. 2011. New England Wild Flower Society's Flora Novae Angliae: a manual for the identification of native and naturalized higher vascular plants of New England. Yale University Press, New Haven, Connecticut and London, United Kingdom. 1008p. 
Hinds, H.R. 2000. Flora of New Brunswick, second edition: a manual for identification of the vascular plants of New Brunswick. Department of Biology, University of New Brunswick, Fredericton. 699p.

Kiger, R.W. \& Porter, D.M. 2001. Categorical glossary for the flora of North America project. Hunt Institute for Botanical Documentation, Carnegie Mellon University, Pittsburgh. 165p.

Komarov, V. L. et al. (eds.). 1963. Flora of the U.S.S.R. (Flora SSSR). 30 vols. Translated from Russian. Israel Program for Scientific Translations, Jerusalem. 18026p.

Marie-Victorin, Frère. 1995. Flore Laurentienne. $3^{\text {rd }}$ ed. Annotated and updated by Luc Brouillet and Isabelle Goulet. University of Montreal Press, Montreal. 1083p.

Morin, N.R.; Whetstone, R.D.; Wilken, D.H. \& Tomlinson, K.L. (eds.). 1989. Floristics for the $21^{\text {st }}$ century. Proceedings of the workshop sponsored by the American Society of Plant Taxonomists, 4-7 May, 1988, Alexandria, Virginia. Monographs in Systematic Botany, Missouri Botanical Garden 28: $1-163$.

Morison, R. 1680-1699. Plantarum historiae universalis oxoniensis. 2 vols. Theathro Sheldoniano, Oxford. $1498 \mathrm{p}$.

Morris R. A.; Dou, L.; Hanken, J.; Kelly, M.; Lowery, D.B. \& Ludäscher, B. et al. 2013. Semantic annotation of mutable data. PLoS ONE 8: e76093. DOI: 10.1371/journal.pone.0076093.

Plukenet, L. 1691-1705. Phytographia, sive, illustriorum \& miniis cognitarum icones tabulis aeneis : summa diligentia elaboratae, quarum unaquaeq[ue] titulis descriptoriis ex notis suis propriis \& characteristicis desumptis insignita, ab aliis ejusdem sortis facile descriminatur. Published by the author. 7 parts.
Porsild, A. E. 1964. Illustrated flora of the Canadian Arctic Archipelago, $2^{\text {nd }}$ ed. Bulletin of the National Museum of Canada 146: 1-218.

Porsild, A.E. \& Cody, W.J. 1980. Vascular plants of continental northwest territories, Canada. National Museum of Natural Sciences, National Museums of Canada, Ottawa. 66 p.

Pursh, F. [1813] 1814. Flora Americae Septentrionalis; or, a systematic arrangement and description of the plants of North America. 2 vols. White, Cochrane, and Co., London. 751p.

Ray, J. 1686-1704. Historia plantarum : species hactenus editas aliasque insuper multas noviter inventas \& descriptas complectens. Vol. 1: 1-983; vol. 2: 9841944; vol. 3: 1-666, 1-135, 1-255. Typis Mariæ Clark, prostant apud Henricum Faithorne [etc.], Londini. 983p.

Reveal, J.L. \& James S. Pringle. 1993. Taxonomic botany and floristics. In: Flora of North America Editorial Committee (eds.). Flora of North America North of Mexico. 18 vols. Oxford University Press, New York and Oxford. Vol. 1, pp. 157-192

Rouleau, E. \& Lamoureaux, G. 1992. Atlas of the vascular plants of the Island of Newfoundland and of Saint-Pierre-et-Miquelon. Fleurbec, Saint-Henride-Lévis. $777 \mathrm{p}$.

Scoggan, H.J. 1978-1979. The flora of Canada. 4 parts. Publications in Botany 7. National Museum of Natural Sciences, Ottawa. 1711p.

Tutin, T.G. et al. (eds.). 1964-1980. Flora Europaea. 5 vols. Cambridge University Press, Cambridge. 2392 p.

Weakley, A. 2012. Flora of the Southern and MidAtlantic States. Working Draft 20 November 2012. University of North Carolina Herbarium, Chapel Hill. 1225p. 
